\title{
Ambroxol suppresses influenza-virus proliferation in the mouse airway by increasing antiviral factor levels
}

\author{
B. Yang*, D.F. Yao*, M. Ohuchi", M. Ide*, M. Yano*, Y. Okumura*, H. Kido*
}

\begin{abstract}
Ambroxol suppresses influenza-virus proliferation in the mouse airway by increasing antiviral factor levels. B. Yang, D.F. Yao, M. Ohuchi, M. Ide, M. Yano, Y. Okumura, H. Kido. C ERS Journals Ltd 2002.

ABSTRACT: The protective effect of ambroxol, a mucolytic agent which has antioxidant properties and stimulates the release of pulmonary surfactant, against influenza-virus proliferation in the airway was investigated in mice.

Ambroxol or the vehicle was administered intraperitoneally twice a day for 5-7 days to mice shortly after intranasal infection with a lethal dose of influenza A/Aichi/68 (H3N2) virus, and the survival rate, virus titre and levels of factors regulating virus proliferation in the airway fluid were analysed.

Ambroxol significantly suppressed virus multiplication and improved the survival rate of mice. The effect of ambroxol reached a peak at $10 \mathrm{mg} \cdot \mathrm{kg}^{-1} \cdot \mathrm{day}^{-1}$, higher doses being less effective. Ambroxol stimulated the release of suppressors of influenza-virus multiplication, such as pulmonary surfactant, mucus protease inhibitor, immunoglobulin (Ig)-A and IgG, although it stimulated the release of a trypsin-type protease that potentiates virus proliferation. In addition, ambroxol transiently suppressed release of the cytokines, tumour necrosis factor- $\alpha$, interferon- $\gamma$ and interleukin-12, into airway fluid.
\end{abstract}

Although ambroxol had several negative effects on the host defence system, overall it strikingly increased the concentrations of suppressors of influenza-virus multiplication in the airway.

Eur Respir J 2002; 19: 952-958.
*Division of Enzyme Chemistry, Institute for Enzyme Research, The University of Tokushima, Tokushima and \#Dept of Microbiology, Kawasaki Medical School, Kurashiki, Japan.

Correspondence: H. Kido, Division of Enzyme Chemistry, Institute for Enzyme Research, The University of Tokushima, Kuramoto-cho 3-18-15, Tokushima 770-8503, Japan.

Fax: 81886337425

E-mail: kido@ier.tokushima-u.ac.jp

Keywords: Ambroxol, cytokine, immunoglobulin-A, influenza-A virus, mucus protease inhibitor, pulmonary surfactant protein A

Received: June 152001

Accepted after revision November 13 2001

This study was supported by a grant-in-aid from the Ministry of Education, Science and Culture of Japan (No. 10557033).
Influenza virus is one of the most common infectious pathogens, and causes considerable morbidity and mortality, particularly in the aged, infants and individuals with certain chronic diseases, and in immunodeficient patients $[1,2]$. The pathogenicity of influenza virus is determined by genetic polymorphism of virus subtypes and host cellular factors which regulate virus entry into target cells. Cleavage of the influenza-virus envelope-glycoprotein precursor, haemagglutinin (HA), which induces the fusion activity of the virus and allows the viral genome to enter the cytoplasm, occurs extracellularly in the membranes of airway epithelial cells and/or in the airway fluid [3-7]. The activity of the processing protease is strictly regulated by endogenous-inhibitory compounds as host defence compounds in the airway, such as mucus protease inhibitor (MPI) in the upper respiratory tract [8] and pulmonary surfactant (PS) in the lower respiratory tract [9]. Surfactant protein A (SP-A), a major sialylated C-type lectin, interacts directly with influenza virus HA and neutralizes the virus [10]. Besides these airway compounds, the mucosal immune system is the first line of immunological defence against pathogens on the mucosal surface. The local levels of secretory immunoglobulin ( $\mathrm{Ig})-\mathrm{A}$ and $\mathrm{IgG}$, correlate with protection against influenza-virus infection [11-13]. These results suggest that the concentrations of these antiviral defensive compounds in the airway fluid significantly affect the pathogenicity of influenzavirus infection.

Ambroxol (2-amino-3,5-dibromo- $N$-(trans-4-hydroxycyclohexyl)benzylamine), known as a mucolytic agent, has been used for the treatment of chronic bronchitis and neonatal respiratory distress syndrome [14]. The pharmacological effects of ambroxol have been reported as mucoregulation on gland cells and enhanced production of surfactant [15]. Furthermore, ambroxol exhibits antioxidant [16] and antiinflammatory properties with reduction of the release of inflammatory cytokines, such as tumour necrosis factor (TNF)- $\alpha$, interleukin (IL)-2, IL-1, IL-4, IL-13 and interferon (IFN)- $\gamma$, from bronchoalveolar macrophages, monocytes and granulocytes [17, 18]. However, little is known about the pharmacological effect of ambroxol on influenza-virus infection in vivo.

In view of these findings, the effect of ambroxol on mice shortly after intranasal infection with a lethal dose of mouse-adapted influenza-A virus, the survival 
rate, the virus titre and concentrations of cellular regulators of virus multiplication and cytokines in the airway fluid were examined.

\section{Materials and methods}

\section{Animals and materials}

Specific pathogen-free female 3-week-old ddY [19] mice weighing 8-10 g (Japan SLC Inc., Shizuoka, Japan) were used. All animals were treated in accordance with the guidelines for animal experimentation set by Tokushima University. Mouse-adapted influenza A/Aichi/68 (H3N2) virus, a laboratory adaptation of the H3N2 pandemic influenza-virus subtype [20], was propagated in 10-day-old embryonated chicken eggs.

\section{Virus infection and administration of ambroxal}

Under anaesthesia with ether, mice were infected intranasally with $6.6 \times 10^{4}$ plaque forming units (PFU) of influenza-A virus in saline, the administration volume being $20 \mu \mathrm{L}$. Within $10-15 \mathrm{~min}$ of infection, each group of 10 animals received intraperitoneally (i.p.), twice daily, $200 \mu \mathrm{L}$ injections of ambroxol (Boehringer Ingelheim, Ingelheim am Rhein, Germany) in saline at a total daily dose of $0,4,10,20$, and $30 \mathrm{mg} \cdot \mathrm{kg}^{-1}$ body weight, respectively, for 7-10 days. For analysis of the concentrations of various compounds in the airway fluid and pathological changes, three groups of animals treated with ambroxol at 0,10 and $30 \mathrm{mg} \cdot \mathrm{kg}^{-1} \cdot \mathrm{day}^{-1}$ were selected, 80 mice being used for each group. The virus levels in the airway fluid were examined by the immunofluorescent cell-counting method as reported previously [21].

\section{Preparation of bronchoalveolar lavage fluid}

Ambroxol was administrated i.p. to each mouse shortly after infection with influenza virus, and then $2 \mathrm{~mL}$ of bronchoalveolar lavage fluid (BALF) from each of five surviving mice was prepared from each group every day for 7 days as reported previously [22]. The BALF was stored at $-80^{\circ} \mathrm{C}$ until use.

\section{Surfactant protein A, cytokine and immunoglobulin assays}

Since there is $95 \%$ identity between the amino acid sequence of the SP-As of mouse and rat [23, 24], and isolated polyclonal antibodies against rat SP-A [6, 25] react with mouse SP-A, the levels of SP-A in BALF of mice were analysed by enzyme-linked immunosorbent assay (ELISA) using monospecific biotinylated and nonbiotinylated antibodies against rat SP-A and mouse SP-A as standards. The levels of cytokines (TNF- $\alpha$, IL-12, IFN- $\gamma$, IL-6 and IL-4) in BALF were determined using ELISA kits (BioSource International, Camarillo, CA, USA) according to the manufacturer's protocol. The levels of IgG and IgA in BALF were also analysed using ELISA kits (Bethyl, TX, USA).

The absorbance at $490 \mathrm{~nm}$ or $450 \mathrm{~nm}$ was read with an ImmunoMini NJ-2300 multiplate reader (Japan Inter Med Co., Ltd, Tokyo, Japan).

\section{Enzyme and inhibitor assays}

The trypsin-type protease activity was analysed as previously described [6], using $N$-tert-butoxycarbonylGln-Ala-Arg-4-methyl-coumaryl-7-amide as the substrate, which resembles the consensus-cleavage motif of HA [4]. The inhibitory activity of MPI which accounts for about $90 \%$ of the protease-inhibitor capacity in BALF $[26,27]$ was analysed as follows: an acid and heat stable MPI was extracted from BALF with $5 \%$ (percent volume in volume $(\mathrm{v} / \mathrm{v})$ ) perchloric acid, and then boiled at $100^{\circ} \mathrm{C}$ for $10 \mathrm{~min}$. Then the supernatant was centrifuged at $15,000 \times g$ for $15 \mathrm{~min}$, adjusted to $\mathrm{pH} 7.0$ with $4 \mathrm{M} \mathrm{KOH}$ and the inhibitor activity of the supernatant was analysed as previously described [8].

\section{Statistics}

All values are given as mean \pm SD. Significant differences between the values for groups treated with ambroxol and controls without treatment were assessed using a paired t-test, a value of $\mathrm{p}<0.05$ was considered to be statistically significant.

\section{Results}

Amboroxol improves the survival rate of mice infected with influenza virus

The administration of ambroxol itself up to the dose $30 \mathrm{mg} \cdot \mathrm{kg}^{-1} \cdot \mathrm{day}^{-1}$ into mice produced no apparent toxicity. After virus infection, significant loss of body weight was evident on day 2 , and all animals $(n=10)$ without ambroxol treatment died within 10 days. Amboroxol treatment significantly improved the survival rates of infected mice in a dose-dependent manner, with a peak effect at a dose of $10 \mathrm{mg} \cdot \mathrm{kg}^{-1} \cdot \mathrm{day}^{-1}$, but higher doses of ambroxol were less effective (fig. 1). When mice were treated with ambroxol at $10 \mathrm{mg} \cdot \mathrm{kg}^{-1} \cdot \mathrm{day}^{-1}$, one-half of them survived a dose of influenza virus, which is normally lethal, at day 10 . The body weight of all surviving animals recovered rapidly after 10 days. Ambroxol inhibited virus proliferation. To analyse the mechanism underlying the improvement of the survival rate of infected mice by ambroxol, the virus titres in BALF were measured. After intranasal infection with influenza-A virus, the virus titre in BALF increased markedly after a lag period of 2 days, reaching a peak on day 5, and viral replication ceased on day 7 , probably due to the host immunological response (fig. 2a). Treatment with ambroxol at a dose of $10 \mathrm{mg} \cdot \mathrm{kg}^{-1} \cdot \mathrm{day}^{-1}$ significantly suppressed viral proliferation, but ambroxol at a dose of $30 \mathrm{mg} \cdot \mathrm{kg}^{-1} \cdot$ day $^{-1}$ was less effective. The pathological changes in the lungs, as macroscopic lung lesions, on 


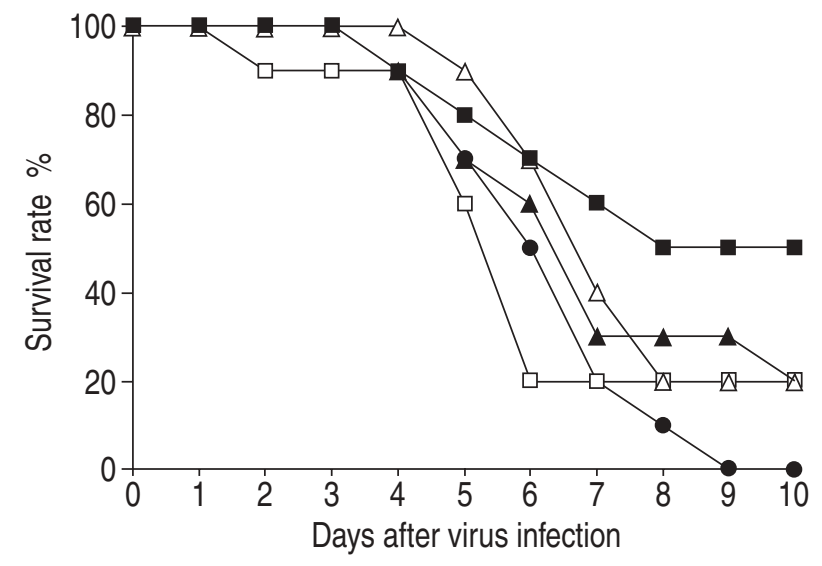

Fig. 1. - The effect of ambroxol on the survival rate of mice infected with influenza-A virus. Mice were infected with $6.6 \times 10^{4}$ plaque forming units of influenza A/Aichi/ 68 virus and then injected with saline (-) or ambroxol i.p. twice daily, at a total daily dose of 4 $(\boldsymbol{\Delta}), 10(\mathbf{\square}), 20(\triangle)$, and $30(\square) \mathrm{mg}^{\mathrm{kg}} \mathrm{kg}^{-1} \cdot \mathrm{day}^{-1}$, respectively.

day 4 (fig. 2b) were also analysed. Severe extensive lesions in the lungs were observed in the infected mice. Treatment with ambroxol at a dose of $10 \mathrm{mg} \cdot \mathrm{kg}^{-1} \cdot \mathrm{day}^{-1}$ restricted the pathological changes but its effect at a dose of $30 \mathrm{mg} \cdot \mathrm{kg}^{-1} \cdot \mathrm{day}^{-1}$ was less significant.

Although virus proliferation in BALF of infected mice had terminated on day 7 , pathological changes in the lungs continued with mild progression and the animals died within 10 days. To elucidate the role of ambroxol in the improvement of the survival rate and suppression of viral proliferation of infected mice, the effects of ambroxol on various cellular factors in BALF that regulate influenza-virus multiplication, and inflammatory cytokines were analysed.

Effects of ambroxol on the levels of activators and inhibitors of influenza-virus multiplication in the airway fluid

Trypsin-type protease, such as tryptase Clara, is constitutively secreted in BALF at basal levels in uninfected mice and rats [6, 9], and influenza-virus infection increased the levels about 6.4-fold with a peak on day 6 (table 1). Treatment with ambroxol at $10 \mathrm{mg} \cdot \mathrm{kg}^{-1} \cdot \mathrm{day}^{-1}$ induced further secretion of the protease from day 1 , which reached a peak on day 5 . Treatment with ambroxol at $30 \mathrm{mg} \cdot \mathrm{kg}^{-1} \cdot \mathrm{day}^{-1}$ further increased the level, with an earlier peak on day 4, after which the level decreased rapidly. Constitutive secretion of trypsin-type protease in mice with sham infection was also, but only slightly, stimulated by ambroxol with a peak on day 4 (table 2).

The effects of ambroxol on the concentrations of antiviral defensive factors in the airway, i.e. SP-A and MPI, are shown in tables 1 and 2. Influenza-virus infection increased the secretion of SP-A and MPI, 6- and 4.4-fold, respectively, with a peak on day 6. Treatment of infected mice with ambroxol at $10 \mathrm{mg} \cdot \mathrm{kg}^{-1} \cdot \mathrm{day}^{-1}$ caused rapid increases in the levels of MPI and SP-A on day 1 and then further and gradual increases in the levels with a peak on day 5, the levels being $29-10$-fold and 8.4-fold the basal

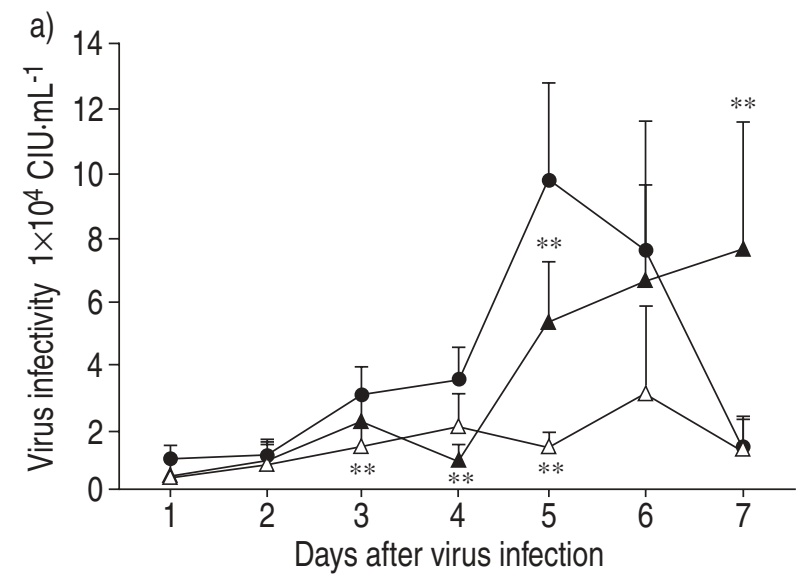

b)

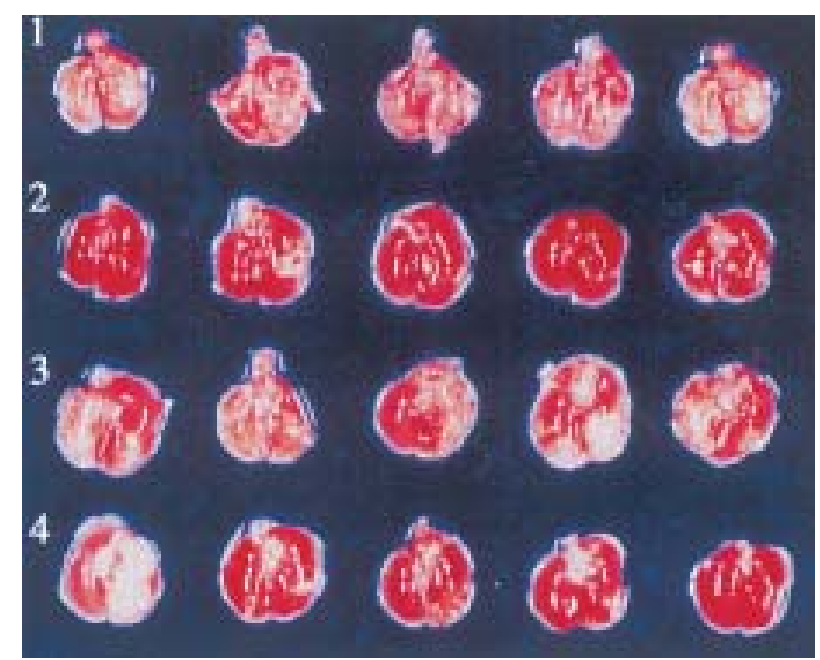

Fig. 2.-a) The effect of ambroxol on virus proliferation in bronchoalveolar lavage fluid. Each group of mice $(\mathrm{n}=80)$ were infected with influenza-A virus and then treated with saline $(\bullet)$ or ambroxol at a total daily dose of $10(\triangle)$ and $30(\mathbf{\Delta})$ $\mathrm{mg} \cdot \mathrm{kg}^{-1} \cdot \mathrm{day}^{-1}$, respectively. CIU: cell infecting unit. Data are presented as mean $\pm \mathrm{SD}$. **: $\mathrm{p}<0.01$. b) Macroscopic lung lesions in mice on day 4 after infection. 1: mice $(n=5)$ on day 4 without infection; 2: mice infected with influenza virus and treated with saline; 3 and 4: mice infected with influenza virus and treated with ambroxal at $10 \mathrm{mg} \cdot \mathrm{kg}^{-1} \cdot \mathrm{day}^{-1}$ and $30 \mathrm{mg} \cdot \mathrm{kg}^{-1} \cdot \mathrm{day}^{-1}$ respectively.

levels of SP-A and MPI, respectively, and remaining high until day 7. However, on treatment of mice with ambroxol at $30 \mathrm{mg} \cdot \mathrm{kg}^{-1} \cdot \mathrm{day}^{-1}$, these peaks were observed earlier on day 4, followed by their rapid reduction. Mild stimulatory effects of ambroxol on the secretion of SP-A and MPI in mice with sham infection were also observed.

\section{Ambroxol stimulates the secretion of mucosal immunoglobulin- $A$ and $-G$}

The basal level of IgA of uninfected mice was very low at $10.3 \pm 6.6 \mathrm{ng} \cdot \mathrm{mL}^{-1}$ and that of $\mathrm{IgG}$, which had probably diffused from the serum, was relatively high at $460 \pm 26.2 \mathrm{ng} \cdot \mathrm{mL}^{-1}$ (figs. $3 \mathrm{a}$ and $4 \mathrm{a}$ ). Treatment 


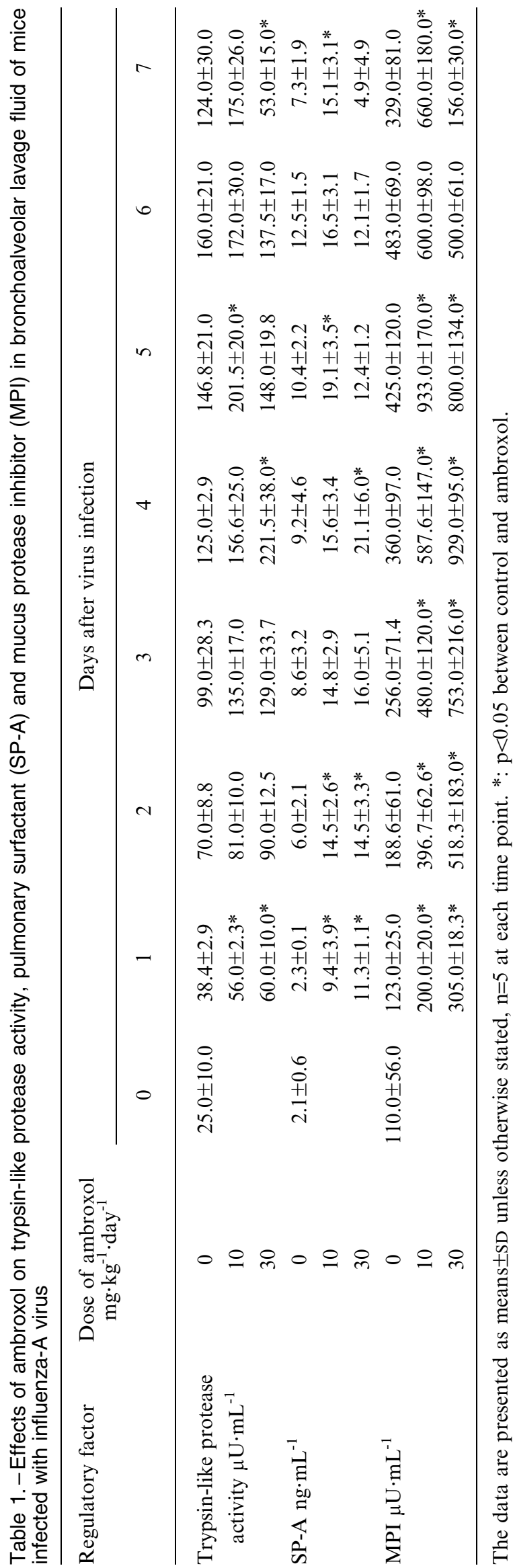

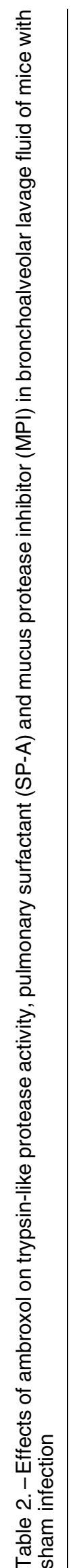

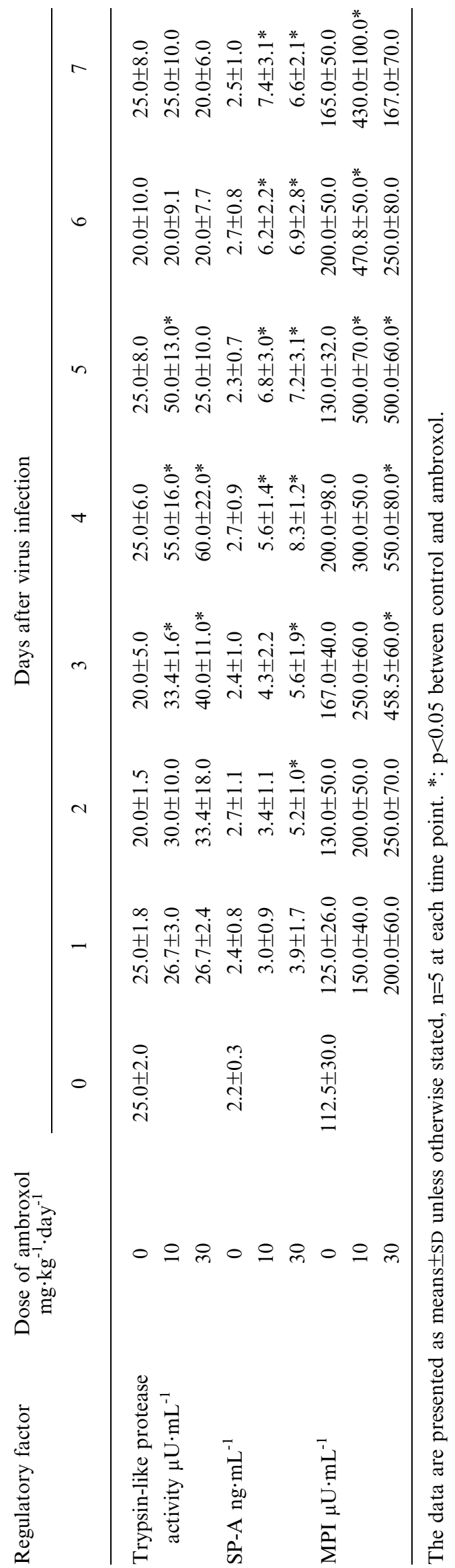



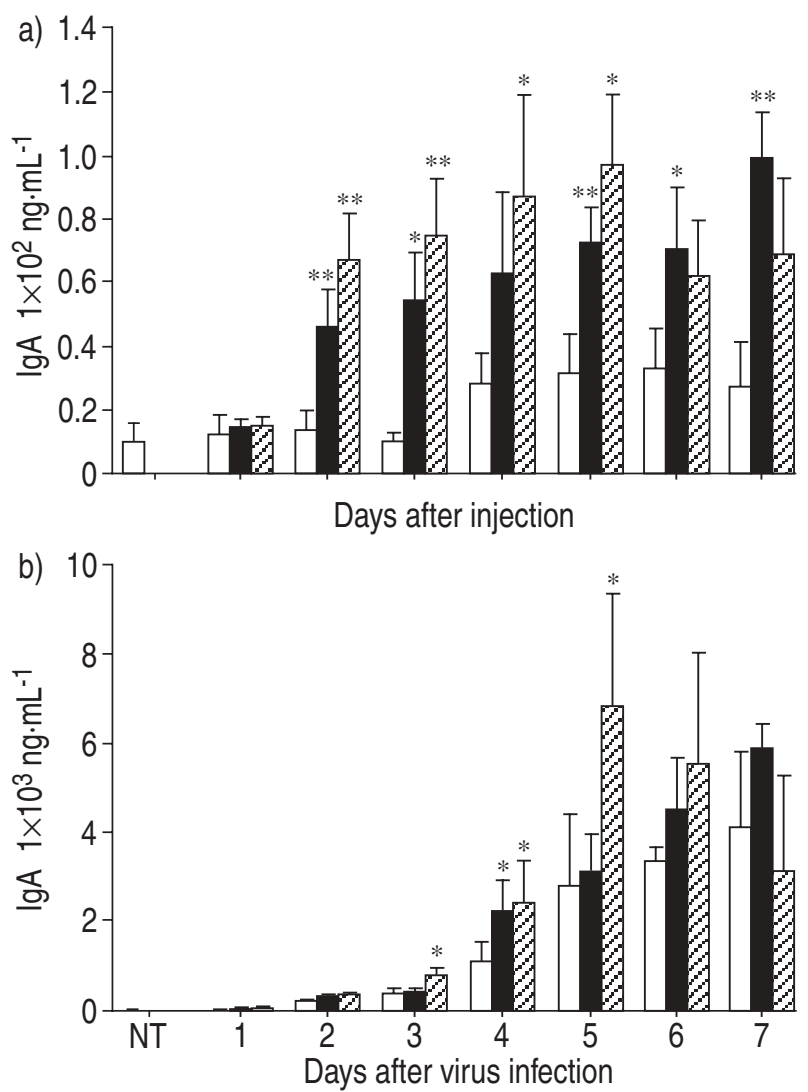

Fig. 3. - The effect of ambroxol on mucosal immunoglobulin (Ig)-A in bronchoalveolar lavage fluid (BALF) of mice with a) sham infection and b) influenza-A virus. $\square$ : IgA levels in BALF of mice treated with saline; $\mathbf{\square}$ : ambroxol at $10 \mathrm{mg} \cdot \mathrm{kg}^{-1} \cdot \mathrm{day}^{-1}$; $\mathbb{Z}$ : ambroxol at $30 \mathrm{mg} \cdot \mathrm{kg}^{-1} \cdot \mathrm{day}^{-1}$. Data are presented as mean \pm SD $(\mathrm{n}=5)$. *: $\mathrm{p}<0.05 ; * *: \mathrm{p}<0.01$. NT: no treatment.

of mice by sham infection with ambroxol at 10 and $30 \mathrm{mg} \cdot \mathrm{kg}^{-1} \cdot \mathrm{day}^{-1}$ stimulated the secretion of $\operatorname{IgA}$ with a peak on days 7 and 5, respectively and both levels being about 10 -fold basal levels. Treatment with ambroxol at 10 and $30 \mathrm{mg} \cdot \mathrm{kg}^{-1} \cdot \mathrm{day}^{-1}$ also increased the levels of $\operatorname{IgG}$ about 1.2 -fold on days 7 and 6 , respectively (fig. 4a). When mice were infected with influenza virus, the levels of $\operatorname{IgA}$ and $\operatorname{IgG}$ in BALF increased markedly after a lag of 1-2 days, and reached peaks with an increase in the IgA level of about 400 -fold on day 7 and in IgG level of 11 -fold on day 6 (figs. $3 \mathrm{~b}$ and $4 \mathrm{~b}$ ). Treatment of infected mice with ambroxol at 10 and $30 \mathrm{mg} \cdot \mathrm{kg}^{-1} \cdot \mathrm{day}^{-1}$ resulted in further increases in the level of $\operatorname{IgA}$ about 600 -fold basal level on day 7 and 700 -fold on day 5, respectively. Ambroxol at 10 and $30 \mathrm{mg} \cdot \mathrm{kg}^{-1} \cdot \mathrm{day}^{-1}$ also stimulated the secretion of IgG moderately in infected mice i.e. about 16 -fold on day 6 and 15 -fold on day 5 , respectively. These results indicate that ambroxol predominantly stimulates release of mucosal IgA induced by infection and also that of IgG moderately.

\section{Effect of ambroxol on cytokine release}

All cytokines examined in BALF of mice with sham infection were under the detection limits. Virus
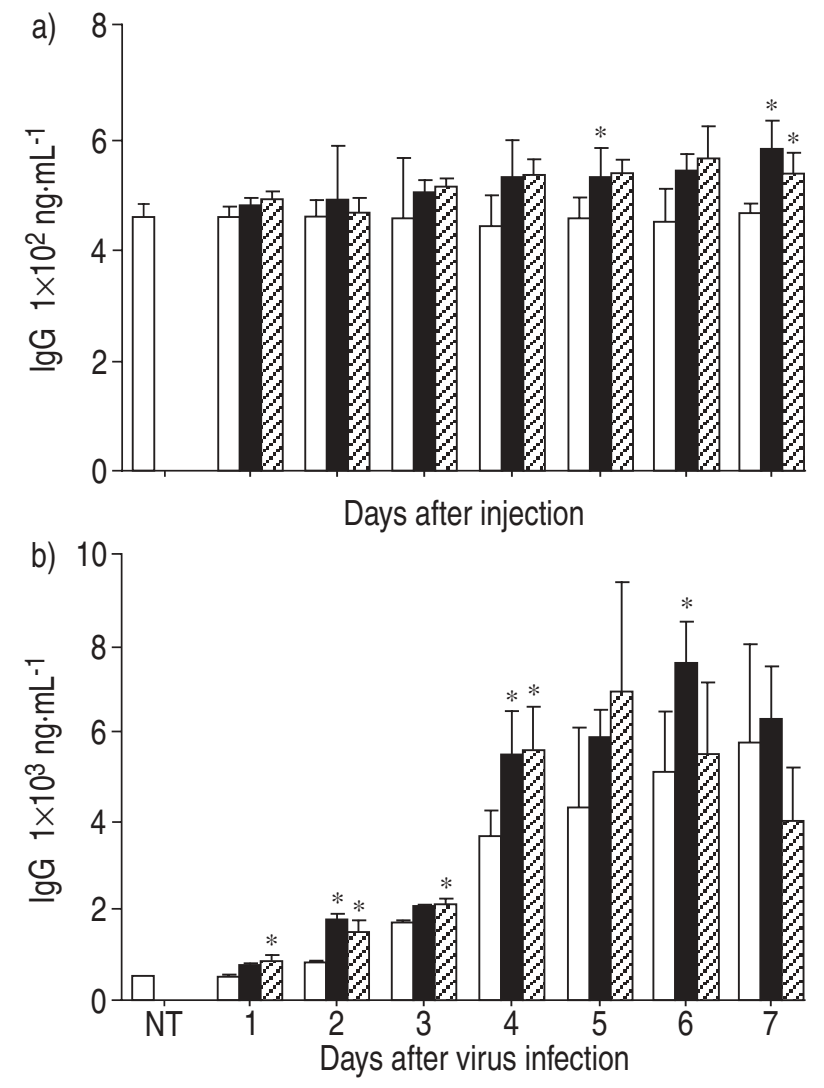

Fig. 4.-The effect of ambroxol on mucosal immunoglobulin (Ig)-G in bronchoalveolar lavage fluid (BALF) of mice with a) sham infection and b) influenza-A virus. $\square$ : IgG levels in BALF of mice treated with saline; $\mathbf{\square}$ : ambroxol at $10 \mathrm{mg} \cdot \mathrm{kg}^{-1} \cdot \mathrm{day}^{-1} ; \mathbb{Z}$ : ambroxol at $30 \mathrm{mg} \cdot \mathrm{kg}^{-1} \cdot \mathrm{day}^{-1}$. Data are presented as mean $\pm \mathrm{SD}$ $(\mathrm{n}=5) .{ }^{*}: \mathrm{p}<0.05$. NT: no treatment.

infection significantly induced the production of all cytokines examined, except IL-4, in BALF with different time/course patterns. When mice were infected, TNF- $\alpha$ at first increased, with a peak on day 1, followed by a rapid decrease with a second small peak on day 6 . The level of IL-6 also rapidly increased after infection on day 1 , the level remaining high with a peak on day 5 , but then starting to decrease on day 7 . The levels of IL-12 and IFN- $\gamma$ gradually increased with peaks on days 4 and 6 , respectively. IL-4 in BALF of infected mice, however, was not detected during infection for 7 days (data not shown). Treatment of infected mice with ambroxol had suppressive effects on the release of TNF- $\alpha$ on days $3-5$, IFN- $\gamma$ on day 1, and IL-12 on day 4, although the effect of ambroxol was not always evident during infection. Treatment with ambroxol, on the contrary, increased the level of IL- 6 on days 4 and 6 in BALF of infected mice (table 3).

\section{Discussion}

In the present study, it was found that ambroxol significantly suppressed the proliferation of influenza virus in the airway and improved the survival rate of mice infected with a lethal dose of influenza-A 
Table 3. - Effects of ambroxol on the levels of tumour necrosis factor (TNF)- $\alpha$, interleukin (IL)-12, interferon (IFN)- $\gamma$ and IL-6 in bronchoalveolar lavage fluid of mice infected with influenza-A virus

\begin{tabular}{|c|c|c|c|c|c|c|c|c|}
\hline \multirow{2}{*}{$\begin{array}{l}\text { Cytokine } \\
\mathrm{pg} \cdot \mathrm{mL}^{-1}\end{array}$} & \multirow{2}{*}{$\begin{array}{c}\text { Dose of } \\
\mathrm{ambroxol}^{-1} \\
\mathrm{mg} \cdot \mathrm{kg}^{-1} \cdot \text { day }^{-1}\end{array}$} & \multicolumn{7}{|c|}{ Days after virus infection } \\
\hline & & 1 & 2 & 3 & 4 & 5 & 6 & 7 \\
\hline \multirow[t]{3}{*}{$\mathrm{TNF}-\alpha$} & 0 & $155.5 \pm 36.2$ & $124.2 \pm 27.8$ & $67.7 \pm 7.3$ & $28.9 \pm 0.2$ & $57.1 \pm 15.8$ & $64.1 \pm 29.3$ & $12.3 \pm 3.2$ \\
\hline & 10 & $150.6 \pm 21.3$ & $108.9 \pm 17.3$ & $57.8 \pm 20.2$ & $23.1 \pm 8.3$ & $29.0 \pm 8.5^{*}$ & $61.6 \pm 24.0$ & $9.8 \pm 2.3$ \\
\hline & 30 & $123.5 \pm 26.4$ & $84.8 \pm 18.8$ & $35.5 \pm 5.4 *$ & $19.2 \pm 3.3^{*}$ & $45.2 \pm 23.2$ & $41.5 \pm 17.0$ & $10.6 \pm 3.6$ \\
\hline \multirow[t]{3}{*}{ IL-12 } & 0 & $22.4 \pm 8.9$ & $93.4 \pm 12.1$ & $138.3 \pm 8.8$ & $184.7 \pm 8.5$ & $74.7 \pm 21.9$ & $32.6 \pm 4.7$ & $88.3 \pm 33.0$ \\
\hline & 10 & $27.3 \pm 7.1$ & $68.5 \pm 12.9^{*}$ & $133.3 \pm 17.2$ & $119.5 \pm 15.8 *$ & $57.4 \pm 16.0$ & $29.4 \pm 6.2$ & $62.5 \pm 27.7$ \\
\hline & 30 & $22.4 \pm 4.1$ & $108.2 \pm 33.3$ & $141.5 \pm 15.1$ & $118.6 \pm 11.4^{*}$ & $62.4 \pm 13.6$ & $44.3 \pm 29.1$ & $95.8 \pm 52.2$ \\
\hline \multirow[t]{3}{*}{ IFN- $\gamma$} & 0 & $17.5 \pm 2.6$ & $12.6 \pm 2.3$ & $3.9 \pm 0.8$ & $7.1 \pm 0.9$ & $40.4 \pm 10.8$ & $49.5 \pm 26.6$ & $5.3 \pm 2.9$ \\
\hline & 10 & $9.4 \pm 2.4^{*}$ & $9.5 \pm 1.8$ & $2.8 \pm 0.9$ & $5.3 \pm 2.8$ & $14.7 \pm 5.3^{*}$ & $39.4 \pm 18.6$ & $4.0 \pm 1.6$ \\
\hline & 30 & $10.4 \pm 2.7 *$ & $9.8 \pm 2.4$ & $4.0 \pm 1.1$ & $10.2 \pm 5.5$ & $32.8 \pm 11.1$ & $61.8 \pm 21.7$ & $5.1 \pm 1.8$ \\
\hline \multirow[t]{3}{*}{ IL-6 } & 0 & $139.1 \pm 45.2$ & $196.0 \pm 22.6$ & $268.0 \pm 75.2$ & $216.2 \pm 60.2$ & $459.8 \pm 127.1$ & $430.0 \pm 63.6$ & $72.1 \pm 13.0$ \\
\hline & 10 & $174.8 \pm 35.0$ & $191.8 \pm 51.9$ & $280.2 \pm 54.2$ & $339.2 \pm 57.1^{*}$ & $540.9 \pm 84.2$ & $503.2 \pm 61.4$ & $73.7 \pm 14.7$ \\
\hline & 30 & $170.8 \pm 28.9$ & $186.7 \pm 19.6$ & $326.2 \pm 44.9$ & $433.5 \pm 101.9^{*}$ & $478.2 \pm 86.4$ & $817.0 \pm 168.0 *$ & $80.0 \pm 17.5$ \\
\hline
\end{tabular}

The data are presented as means \pm SD unless otherwise stated, $\mathrm{n}=5$ at each time point. *: $\mathrm{p}<0.05$ between control and ambroxol.

virus. Influenza virus is exclusively pneumotropic, and its pathogenicity and replication are determined by various host cellular factors, and the adaptive immune responses of $\mathrm{T}$ - and B-cells in the airway.

In the respiratory tracts of animals, cellular factors which regulate influenza-virus multiplication, such as a trypsin-type protease, tryptase Clara [6, 7], and inhibitors of the protease, MPI [8] and PS [9], have been reported. The level of trypsin-type protease under conventional airway conditions is higher than those of inhibitors, which enables infection by, and proliferation of, influenza virus $[6,8,9]$. PS, coating the alveolar epithelium, binds tryptase Clara and inhibits its proteolytic activity [9, 28]. Influenza-virus infection induced secretion of the virus-potentiating protease as well as its inhibitors. Ambroxol stimulated further release of these factors in infected mice and changed the balance of the protease and inhibitors; the level of the protease induced by infection was further increased 1.3-1.4-fold, and those of SP-A and MPI 1.5-1.7-fold and 1.9-fold, respectively, by ambroxol. These results indicate that ambroxol increased the proportion of inhibitory compounds in the airway fluid of infected mice.

Another significant effect of ambroxol was an increase in the release of mucus IgA of infected and sham-infected mice, as shown in figure 3 . The drug also stimulated the release of IgG moderately (fig. 4). In mice with sham infection, ambroxol stimulated the release of $\operatorname{IgA}$ about 10 -fold, and that of $\mathrm{IgG}$ about 1.2-fold the basal levels. After virus infection, the levels of IgA and IgG in BALF were markedly increased. Treatment of infected mice with ambroxol further increased the maximum levels of $\operatorname{IgA}$ and $\mathrm{IgG}$ by $1.5-1.8$-fold and 1.45-fold, respectively, indicating that the increases caused by ambroxol in the levels of $\operatorname{IgA}$ and $\operatorname{IgG}$ also play a role in the improvement of the survival rate of infected mice.

The mechanisms underlying the stimulation by ambroxol of the release of IgA, IgG, SP-A, MPI and trypsin-type protease from various secretory epithelial cells are not understood, but the findings suggest that ambroxol stimulates several target cells in the upper and lower airways. When mice were treated with the optimal dose of ambroxol of $10 \mathrm{mg} \cdot \mathrm{kg}^{-1} \cdot \mathrm{day}^{-1}$, the levels of inhibitory compounds for virus multiplication and immunoglobulins in the airway fluid increased with time after treatment and the levels remained high until the termination of viral replication on day 7 . However, treatment with the higher dose of ambroxol rapidly increased these levels, the peaks being reached earlier on days $4-5$, but the levels could not be kept high during infection. These results indicate that ambroxol causes stimulation of secretion rather than synthesis of inhibitory compounds and trypsin-type protease in the airway. In addition, the maintenance of these inhibitory compounds at high levels until day 7 may be necessary for improved survival of infected mice.

Although virus proliferation had terminated on day 7 (fig. 2), lung inflammation continued with mild progression. A number of studies have recently shown that ambroxol exhibits anti-inflammatory properties [16], with reduction of inflammatory cytokine production [17, 18]. In the present study, it was also found that ambroxol suppressed the levels of inflammatory cytokines, TNF- $\alpha$ and IFN- $\gamma$, in the airway fluid of infected mice, although the effect was not always evident during infection. Both intranasal IL-6 and IL-12 have an adjuvant effect on the induction of systemic mucosal immunity, and only IL-12 induces secretory IgA responses [29]. Treatment of infected mice with ambroxol increased the levels of IL-6 in BALF on days 4 and 6 and transiently suppressed that of IL-12 on day 4.

Although ambroxol had several negative effects on host defence systems against influenza-virus infection in mice, such as an increase in the level of trypsin-type protease and transient suppression of the release of an adjuvant cytokine, IL-12, ambroxol overall strikingly suppressed virus multiplication in the airway fluid and significantly improved the survival rate of mice infected with influenza-A virus. These latter effects of ambroxol may be explained by increases in the levels of inhibitors for virus multiplication, such as SP-A, MPI, IgA and IgG, as well as by 
suppression of the release of inflammatory cytokines in the airway.

Further studies are needed to clarify whether ambroxol might possibly be applied clinically for the treatment or prevention of influenza-virus infection in humans.

\section{References}

1. Kim HW, Brandt CD, Arrobio JO, Murphy B, Chanock RM, Parrott RH. Influenza A and B virus infection in infants and young children during the years 1957-1976. Am J Epidemiol 1979; 109: 464-479.

2. Barker WH, Mullooly JP. Impact of epidemic type A influenza in a defined adult population. Am J Epidemiol 1980; 112: 798-813.

3. Klenk HD, Garten W. Host cell proteases controlling virus pathogenicity. Trends Microbiol 1994; 2: 39-43.

4. Klenk HD, Rott R. The molecular biology of influenza virus pathogenicity. Adv Virus Res 1988; 34: 247-281.

5. Homma M, Ohuchi M. Trypsin action on the growth of Sendai virus in tissue culture cells. J Virol 1973; 12: 1457-1465.

6. Kido H, Yokogoshi Y, Sakai K, et al. Isolation and characterization of a novel trypsin-like protease found in rat bronchiolar epithelial Clara cells. $J$ Biol Chem 1992; 267: 13573-13579.

7. Tashiro M, Yokogoshi Y, Tobita K, Seto JT, Rott R, Kido H. Tryptase Clara, an activating protease for Sendai virus in rat lungs, is involved in pneumopathogenicity. J Virol 1992; 66: 7211-7216.

8. Beppu Y, Imamura $\mathrm{Y}$, Tashiro $\mathrm{M}$, Towatari $\mathrm{T}$, Ariga $\mathrm{H}$, Kido $\mathrm{H}$. Human Mucus protease inhibitor in airway fluids is a potential defensive compound against infection with influenza $\mathrm{A}$ and Sendai viruses. J Biochem 1997; 121: 309-316.

9. Kido H, Sakai K, Kishino Y, Tashiro M. A pulmonary surfactant is a potential endogenous inhibitor of proteolytic activation of Sendai virus and influenza virus. FEBS Lett 1993; 322: 115-119.

10. Benne CA, Kraaijeveld CA, van Strijp JAG, et al. Interactions of surfactant protein A with influenza A viruses: binding and neutralization. $J$ lnfect Dis 1995; 171: 335-341.

11. Liew FY, Russell SM, Appleyard G, Brand CM, Beale J. Cross-protection in mice infected with influenza A virus by the respiratory route is correlated with local IgA rather than serum antibody or cytotoxic $\mathrm{T}$ cell reactivity. Eur J Immunol 1984; 14: 350-356.

12. Tamura S, Funato H, Hirabayashi Y, et al. Functional role of respiratory tract haemagglutinin-specific IgA antibodies in protection against influenza. Vaccine 1990; 8: 479-485.

13. Wright PF, Murphy BR, Kervina M, Lawrence EM, Phelan MA, Karzon DT. Secretory immunological response after intranasal inactivated influenza A virus vaccinations: evidence for immunoglobulin $\mathrm{A}$ memory. Infect Immun 1983; 40: 1092-1095.

14. Germouty J, Jirou-Najou J. Clinical efficacy of ambroxol in the treatment of bronchial stasis. Respiration 1987; 51: 37-41

15. Heath MF, Jacobson W. The inhibition of lysosomal phospholipase A from rabbit lung by ambroxol and its consequences for pulmonary surfactant. Lung 1985; 163: 337-344.

16. Gillissen A, Scharling B, Jaworska M, Bertling A, Rasche K, Schultze-Werninghaus G. Oxidant scavenger function of ambroxol in vitro: a comparison with N-acetylcysteine AC. Res Exp Med (Berl) 1997; 196: 389-398.

17. Pfeifer S, Zissel G, Kienast K, Muller-Quernheim J. Reduction of cytokine release from blood and bronchoalveolar mononuclear cells by ambroxol. Eur J Med Res 1997; 2: 129-132.

18. GiWs BF, Schmutzler W, Vollrath IB, et al. Ambroxol inhibits the release of histamine, leukotriemes and cytokines from human leukocytes and mast cells. Inflamm Res 1999; 48: 86-93.

19. Tanaka S, Matsuzawa A. The history of the "deutche Maus" the origin of the dd mouse group. Exp Anim 1990; 39: 141-153.

20. Ovcharenko AV, Zhirnov OP. Aprotinin aerosol treatment of influenza and paramyxovirus bronchopneumonia of mice. Antiviral Res 1994; 23: 107-118.

21. Tashiro M, Homrna M. Pneumotropism of Sendai virus in relation to protease mediated activation in mouse lungs. Infect Immun 1983; 39: 879-888.

22. Singh G, Katyal SL. An immunologic study of the secretory products of rat clara cells. J Histochem Cytochem 1984; 32: 49-54.

23. Korfhagen TR, Bruno MD, Glasser SW, et al. Murine pulmonary surfactant SP-A: gene cloning, sequence, and transcripitional activity. Am J Physiol 1992; 263: L546-L554.

24. Lacaze-Masmonteil T, Fraslon C, Bourban J, Raymondjean M, Kahn A. Characterization of the rat pulmonary surfactant protein A promoter. Eur J Biochem 1992; 206: 613-623.

25. Sakai K, Kweon MN, Kohri T, Kishino Y. Effects of a pulmonary surfactant and surfactant protein A on phagocytosis of fractionated alveolar macrophages: relationship to starvation. Cell Mol Biol 1992; 38: 123130.

26. Stolk J, Rossie W, Dijkman JH. Apocynin improves the efficacy of a secretory leukocyte protease inhibitor in experimental emphysema. Am J Respir Crit Care Med 1994; 150: 1628-1631.

27. Ohlsson $\mathrm{K}$, Tegner $\mathrm{H}$, Akesson U. Isolation and partial characterization of a low molecular weight acid stable protease inhibitor from human bronchial secretions. Hoppe Seylers Z Phusiol Chem 1977; 358: 583-589.

28. Kido H, Murakami M, Oba K, Chen Y, Towatari T. Cellular proteinases trigger the infectivity of the influenza A and Sendai viruses. Mol Cells 1999; 9: 235-244.

29. Boyaka PN, Marinaro M, Jackson R, et al. IL-12 is an effective adjuvant for induction of mucosal immunity. J Immunol 1999; 162: 122-128. 